\title{
Implementasi Metode Talaqqi dalam Pembelajaran Tahsin Dan Tahfiz Al- Qur'an
}

\author{
Azis Rizalludin \\ UIN Sunan Gunung Djati Bandung, Indonesia \\ Email: Ar1112991@gmail.com
}

\begin{abstract}
Level of students' skills in reading al-Qur'an at SDIT Khaira Ummah Tanjungsari that have not met the specified achievement indicators. This is based on observations in the field conducted by researchers in class III SDIT Khaira Ummah Tanjungsari 2016/2017 school year. There were 10 students (40\%) in the category of not fluently reading the Koran (halting) and 8 students (32\%) were in the category of not fluent in reading the Koran from a total of 25 students in grade 3 SDIT Khaira Ummah Tanjungsari. This study aims to describe the implementation of the talaqqi method in learning tahsin and tahfiz al-Qur'an (Research in Class III SDIT Khaira Ummah Tanjungsari). Namely describing the design of learning tahsin and tahfiz al-Qur'an using the talaqqi method, describing the implementation and evaluation of learning tahsin and tahfiz al-Qur'an by using the talaqqi method in grade 3 SDIT Khaira Ummah Tanjungsari. The research uses descriptive qualitative approach and the method used is descriptive analysis method, while the data collection methods used include observation, interview or interview, documentation and literature study. The results of this study indicate that the design of the learning of tahsin and tahfiz alQur'an using the talaqqi method at SDIT Khaira Ummah Tanjungsari includes the design of teacher arrangements, student arrangements, time and place settings for learning as well as designs of teaching materials for tahsin and tahfiz al-Qur'an, Implementation of learning tahsin and tahfiz al-Qur'an using the talaqqi method.
\end{abstract}

Keywords: Implementation, learning, tahsin and tahfidz

\begin{abstract}
ABSTRAK
Tingkat keterampilan siswa dalam membaca al-Qur'an di SDIT Khaira Ummah Tanjungsari yang belum memenuhi indikator pencapaian yang telah ditetapkan. Hal ini didasari atas pengamatan di lapangan yang peneliti lakukan di kelas III SDIT Khaira Ummah Tanjungsari tahun pelajaran 2016/2017. Terdapat sebanyak 10 siswa (40\%) pada kategori tidak lancar membaca al-Qur'an (terbata-bata) dan 8 siswa (32\%) berada pada kategori kurang lancar dalam membaca al-Qur'an dari total 25 siswa di kelas 3 SDIT Khaira Ummah Tanjungsari. Penelitianini bertujuan untuk mendeskripsikan implementasi metode talaqqi dalam pembelajaran tahsin dan tahfiz al-Qur'an (Penelitian di Kelas III SDIT Khaira Ummah Tanjungsari). Yaitu menggambarkan desain pembelajaran tahsin dan tahfiz al-Qur'an dengan menggunakan metode talaqqi, menggambarkan pelaksanaan dan evaluasi pembelajaran tahsin dan tahfiz al-Qur'an dengan menggunakan metode talaqqi di kelas 3 SDIT Khaira Ummah Tanjungsari. penelitian menggunakan pendekatan kualitatif deskriptif dan metode yang digunakan adalah metode deskriptif analisis, sedangkan metode pengumpulan data yang digunakan meliputi observasi, interview atau wawancara, dokumentasi dan studi pustaka. Hasil penelitian ini menunjukan bahwa Desain pembelajaran tahsin dan tahfizal-Qur'an dengan menggunakan metode talaqqi di SDIT Khaira Ummah Tanjungsari mencakup desain pengaturan guru, pengaturan siswa, pengaturan waktu dan tempat belajar serta desain materi ajar tahsin dan tahfiz al-Qur'an, Pelaksanaan pembelajaran tahsin dan tahfiz al-Qur'an dengan menggunakan metode talaqqi.
\end{abstract}

Kata Kunci : Implementasi, pembelajaran, tahsin dan tahfid

* Azis Rizalludin

Received: November 01, 2019; Revised: November 07, 2019; Accepted: Desember 15, 2019 


\section{PENDAHULUAN}

Penerapan sebuah metode pembelajaran al-Qur`an pada lembaga pendidikan Islam merupakan sesuatu yang mutlak adanya. Sementara pengembangan metode-metode pembelajaran al-Qur`an di Indonesia saat ini begitu pesat, ini menunjukkan kesadaran dan gairah masyarakat akan pentingnya mengaji dan mengkaji kitab suci al-Qur`an semakin baik dan senantiasa diupayakan agar terus dikembangkan. Para pakar al-Qur'an telah berupaya untuk memenuhi kebutuhan dan tuntutan masyarakat akan hal tersebut. sehingga penelitian mengenai metode pembelajaran al-Qur'an telah banyak dilakukan dan cukup menarik perhatian bagi kalangan praktisi pendidikan (Abdul Khaliq, 2006).

Penggunaan metode pembelajaran dalam meningkatkan peranan pengajaran agar lebih dapat diterima oleh siswa merupakan suatu keharusan, karena dalam tujuan mengajar disebutkan agar bahan ajar yang diberikan kepada siswa dapat diserap dengan baik, sementara proses belajar mengajar merupakan komunikasi timbal balik antar guru dan murid, keduanya sama-sama aktif dalam ambil bagian sesuai dengan kedudukannya dan posisinya masing-masing. Maka untuk dapat aktif ambil bagian tersebut, dibutuhkan cara-cara atau metode-metode yang sesuai dengan kondisi yang ada.

Metode talaqqi merupakan metode yang diajarkan malaikat Jibril kepada Nabi Saw dalam menyampaikan al-Qur'an, sebagaimana ketika wahyu pertama yaitu surat al-Alaq:1-5 diturunkan di Gua Hiro. Bahkan dalam beberapa riwayat diceritakan bahwa Nabi Saw selalu mentalaqqikan bacaan al-Qur'an kepada malaikat Jibril setiap bulan Ramdhan. Metode talaqqi juga diajarkan pula oleh Rasulullah kepada para sahabatnya.

Adapun model pembelajaran dengan metode talaqqi masa Rasulullah terdapat dua macam kategori, yaitu: Seorang guru membaca atau menyampaikan ilmunya di depan murid-muridnya dan para murid menyimaknya, dan terkadang di akhiri dengan pertanyaan-pertanyaan dan Murid membaca di depan guru kemudian guru membenarkan jika ada kesalahan dalam bacaan murid.

Pelaksanaan pembelajaran al-Qur'an dengan metode talaqqi yaitu belajar al-Qur'an dengan dicontohkan seorang pembimbing, peserta didik menyimak apa yang disampaikan oleh pembimbing kemudian mengikuti bacaannya dan akan dikoreksi oleh pembimbing terkait dengan kesalahankesalahan yang ada ketika membaca al-Qur'an. Metode ini bisa dilakukan secara private yaitu seorang peserta didik berhadapun langsung dengan pembimbing dan bisa juga dilakukan secara jama'i (bersama). Namun untuk mencapai hasil yang maksimal jumlah peserta didik untuk metode talaqqi secara bersama adalah 3 sampai 10 orang.

Evaluasi pembelajaran tahsin dan tahfiz al-Qur'an dengan metode talaqqi dilakukan untuk mengetahui tingkat pencapaian kompetensi peserta didik, serta digunakan sebagai bahan penyusunan laporan kemajuan hasil belajar serta memperbaiki proses pembelajaran. Evaluasi ini dapat dilakukan secara subyektif maupun obyektif. Secara subyektif yaitu dengan mengamati sikap dan perilaku siswa selama mengikuti pembelajaran tahsin dan tahfiz al-Qur'an, apakah terlihat antusias atau kurang antusias dalam proses pembelajaran tahsin dan tahfiz al-Qur'an. Adapun secara obyektif yaitu dengan melakukan tes lisan maupun tulisan untuk mengetahui hasil belajar siswa pada mata pelajaran tahsin dan tahfiz alQur'an, apakah sudah memenuhi target yang hendak dicapai atau belum. Tes tersebut dapat berupa praktek tilawah dan muroja'ah hafalan yang dilaksanakan secara langsung dihadapan pembimbingnya.

SDIT Khaira Ummah Tanjungsari merupakan lembaga pendidikan Islam tingkat sekolah dasar dengan beberapa program unggulan yang ditawarkan yaitu pembelajaran tahsin dan tahfiz al-Qur'an. Adanya pembelajaran tahsin dan tahfiz al-Qur'an sebagai bentuk antusias pengurus lembaga pendidik dan dalam membina anak didiknya untuk mencetak generasi yang peduli terhadap kalam Illahi, sehingga menghasilkan generasi yang memiliki kualitas bacaan yang tinggi sesuai kaidah ilmu tahsin. 
Dari berbagai metodologi pembelajaran al-Qur'an yang ada, metode talaqqi merupakan salah satu metode yang banyak digunakan oleh para pengajar di berbagai macam tingkatan sekolah, sebagaimana yang diterapkan di SDIT Khaira Ummah Tanjungsari. Adapun alasan pemilihan metode talaqqi di sekolah ini adalah karena metode talaqqi memiliki beberapa keunggulan dibanding metode yang lain, diantaranya: Metode talaqqi merupakan salah satu metode yang diterapkan oleh Rasulullah dalam mendidik sahabatsahabatnya, Metode talaqqi memudahkan pengajar memilih cara yang tepat dalam menyampaikan ilmu, karena dengan bertemu langsung antara pengajar dan peserta didik, membuat pengajar lebih mudah mengenali kepribadian peserta didik, Metode talaqqi memudahkan pedidik mengawasi serta mengevaluasi hasil belajar peserta didik secara langsung dan Keberadaan metode talaqqi merupakan bagian penting dalam penyebaran agama Islam.

Adapun alasan lain penggunaan metode talaqqi di SDIT Khaira Ummah Tanjungsari karena berdasarkan latar belakang pengajar tahsin yang berbeda-beda yaitu dari berbagai lembaga kajian ilmu tahsin seperti Tar-Q, Cordoba, Maqdis dan lain-lain. Pihak sekolah memutuskan tidak mengadopsi metode dari salah satu lembaga kajian ilmu tahsin tertentu, melainkan mengambil persamaan dan keunggulan dari berbagai metode yang disampaikan oleh para pengajar tahsin, maka diputuskan metode yang dirasa sesuai untuk diterapkan di SDIT Khaira Ummah Tanjungsari adalah metode talaqqi.

Menurut hasil observasi peneliti di SDIT Khaira Ummah Tanjungsari, kendala yang muncul dalam pembelajaran tahsin dan tahfiz al-Qur'an di sekolah tersebut adalah kurangnya variasi metode yang menggunakan cara belajar secara auditori saja (hanya mendengarkan dan menirukan), semangat siswa yang naik-turun, siswa kurang konsentrasi terhadap materi tahsin dan tahfiz al-Qur'an, perbedaan cara belajar serta kemampuan kognitif yang berbeda-beda antar individu. Adapun kendala yang dialamai pengajar adalah kurang mampu memonitoring kemampuan siswa secara individu, menejemen kelas yang kurang kondusif, kurang memotivasi dan menarik minat siswa, kurang kreatif dalam memberikan perlakuan khusus bagi siswa yang memiliki gaya belajar yang berbeda. Akibatnya bagi siswa yang memiliki kendala dalam gaya belajar berbeda dengan siswa kebanyakan, akan merasa kesulitan mengikuti proses pembelajaran tahsin dan tahfiz al-Qur'an, membuat siswa bosan dan jenuh serta merasa terbebani dalam proses pembelajaran tahsin dan tahfiz al-Qur'an.

Adapun dari pengamatan awal dilapangan, yang terjadi dalam salah satu kelas, seperti yang ada di kelas 3 SDIT Khaira Ummah Tanjungsari, ternyata tidak semua siswa memiliki kemampuan yang baik dalam membaca al-Qur'an, padahal kelas 3 ini merupakan salah satu tolak ukur dan indikator berhasil atau tidaknya pembelajaran tingkat pemula serta pra tahsin yang telah dilaksanakan di kelas 1 dan 2 . Tercatat dari total 25 siswa kelas 3, sebanyak 10 siswa (40\%) berada pada kategori tidak lancar (terbatabata), 8 siswa (32\%) berada pada kategori kurang lancar dalam membaca al-Qur'an dan 7 siswa (28\%) berada pada kategori lancar atau mahir dalam membaca al-Qur'an berdasarkan indikator pencapaian dalam pembelajaran tahsin. Kegiatan evaluasi yang dilaksanakan pada jenjang kelas 3 ini bertujuan agar dapat menentukan langkah antisipasi berikutnya bagi siswa yang belum mencapai target.

\section{METODE PENELITIAN}

Metode penelitian yang digunakan yaitu menggunakan pendekatan kualitatif dengan cara mengambil data langsung kelapangan,observasi,wawancara serta hasil data yang didapat dianalisis menjadi sebuah narasi deskriptif (Suryabrata, 2013). Jenis penelitian kualitatif yang digunakan dalam penelitian ini adalah fenomenologis. Jenis penelitian fenomenologis dapat mengungkap fakta secara alamiah berdasarkan perspektif pelaku atau subjek penelitian bukan berdasarkan persepsi penelit i(Buckley Philip dan Irawan, 2015) . Karena subjek penelitiannya berada dalam konteks didaktik metodik, 
maka metode penelitian kualitatif fenomenologis yang cocok dengan penelitian ini adalah metode penelitian kualitatif khusus untuk manajemen pendidikan atau manajemen pembelajaran atau yang sesuai dengan paradigma keilmuan manajemen pendidikan Islam (Irawan, 2016).

\section{HASIL DAN PEMBAHASAN}

Untuk menganalisis dan membahas penelitian ini, penulis memanfaatkan beberapa teori yang sudah diuraikan di bab dua dengan fokus kajian implementasi metode talaqqi dalam pembelajaran tahsin dan tahfiz al-Qur'an di SDIT Khaira Ummah Tanjungsari.

Berdasarkan hasil pengamatan, wawancara dan dokumentasi, tujuan utama dari pembelajaran tahsin dan tahfiz al-Qur'an di SDIT Khaira Ummah Tanjungsari adalah agar peserta didik dapat membaca al-Qur'an dengan baik dan benar serta berakhlaq Qur'ani. Adapun alasan pemilihan metode talaqqi merupakan salah satu bentuk usaha pihak sekolah dalam memilih metode yang sesuai dengan usia perkembangan siswa, dimana usia anak SD merupakan usia peniru, yaitu menirukan apa yang dicontohkan oleh orang dewasa (guru). Maka penggunaan metode talaqqi dianggap yang paling pas, karena dalam proses pembelajarannya memberikan contoh bacaan al-Qur'an yang benar sesuai kaidah ilmu tajwid secara musyafahah atau bertemunya seorang guru dengan murid.

Adapun alasan lain pemilihan metode talaqqi dalam pembelajaran tahsin dan tahfiz al-Qur'an di SDIT Khaira Ummah Tanjungsari karena metode talaqqi memiliki beberapa kelebihan dibanding dengan metode lain, diantaranya yaitu: Pertama, karena terjadi hubungan yang erat dan harmonis antara guru dengan murid. Kedua, memungkinkan bagi seorang guru untuk mengawasi, menilai dan membimbing secara maksimal kemampuan menghafal muridnya. Ketiga, peneguran, saran dan kritik yang jelas tanpa harus mereka-reka tentang hafalan yang disetorkan karena seorang murid berhadapan dengan guru secara langsung. Keempat,guru dapat mengetahui secara pasti kualitas hafalan muridnya. Kelima, metode talaqqi memudahkan pengajar memilih cara yang tepat dalam menyampaikan ilmu, karena dengan bertemu langsung antara pengajar dan peserta didik, membuat pengajar lebih mudah mengenali kepribadian peserta didik. Keenam,metode talaqqi memudahkan pedidik mengawasi serta mengevaluasi hasil belajar peserta didik secara langsung. Ketujuh, keberadaan metode talaqqi merupakan bagian penting dalam penyebaran agama Islam, karena ada bagian yang tidak bisa di miliki oleh metode-metode pengajaran lainnya seperti saling mengerti antara pendidik dan peserta didik (Wahid, 2013).

Menurut peneliti, pemilihan metode talaqqi yang diterapkan dalam pembelajaran tahsin dan tahfiz al-Qur'an di SDIT Khaira Ummah Tanjungsari sudah sesuai. Metode talaqqi merupakan salah satu metode yang pertama dalam pembelajaran al-Qur'an, sebagaimana dalam sejarah Islam, metode talaqqi ini sudah dipakai pada zaman Rasulullah dan para sahabat. Desain pembelajaran tahsin dan tahfiz al-Qur'an dengan menggunakan metode talaqqi . Pembelajaran tahsin dan tahfiz al-Qur'an dengan menggunakan metode talaqqi di SDIT Khaira Ummah Tanjungsari di mulai dari desain pembelajaran yang dilakukan oleh kepala sekolah, bagian kurikulum serta koordinator tahsin dan tahfiz al-Qur'an. Desain pembelajaran tahsin dan tahfiz al-Qur'an tersebut mencakup desain pengaturan guru, pengaturan siswa, pengaturan waktu dan tempat belajar serta desain materi ajar.

Dalam desain pengaturan guru, tidak sembarang guru bisa menjadi pengajar tahsin dan tahfiz alQur'an di SDIT Khaira Ummah Tanjungsari. Proses pemilihan pengajar tahsin dan tahfiz al-Qur'an ditentukan saat perekrutan calon guru baru di SDIT Khaira Ummah Tanjungsari. Kriteria dapat membaca al-Qur'an dengan baik dan benar menjadi prioritas utama dalam pemilihan calon guru. Setelah terpilih sejumlah guru sesuai kebutuhan sekolah, kemudian di adakan lagi seleksi untuk calon pengajar tahsin dan 
tahfiz al-Qur'an berdasarkan kemampuan bacaan serta bagaimana cara mengajarnya berdasarkan hasil test micro teaching.

Guru yang mengajar tahsin dan tahfiz al-Qur'an dipilih bukan berdasarkan bidang keahlian (jurusan PT asal) tetapi berdasarkan kemampuan membaca al-Qur'an. selain itu, guru yang mengajar tahsin dan tahfiz al-Qur'an harus memenuhi kualifikasi tertentu, yaitu pernah mengikuti pembinaan tahsin. Adapun para pengajar tahsin dan tahfiz al-Qur'an di SDIT Khaira Ummah Tanjungsari rata-rata pernah mengikuti pembinaan tahsin di berbagai lembaga tahsin dengan berbagai metode. Untuk meningkatkan kemampuan serta penyamaan visi dalam mengajar tahsin dan tahfiz al-Qur'an setiap akhir bulan diadakan up greding dan pembinaan tahsin untuk para pengajar tahsin (Annuri, 2013).

Pembinaan tahsin dan up greding ini merupakani bentuk komitmen sekolah terhadap penggunaan metode talaqqi dalam pembelajaran tahsin dan tahfiz al-Qur'an, sekolah mewajibkan kepada setiap guru tahsin untuk mengikuti pembinaan dengan metode talaqqi. Kebijakan ini atas dasar penyeragaman metode agar seluruh peserta didik mengikuti pembelajaran tahsin dengan metode talaqqi walaupun para pengajar tahsin memiliki latar belakang metode yang berbeda-beda. Hal ini dimaksudkan agar setiap pengajar memiliki kesamaan visi dalam menerapkan metode talaqqi dalam pembelajaran tahsin dan tahfiz al-Qur'an.

Guru merupakan tempat yang sentral yang keberadaannnya merupakan penentu bagi keberhasilan pembelajaran. Guru merupakan komponen utama yang sangat penting dalam proses pembelajaran karena tugas guru bukan hanya sebagai fasilitator namun ada dua tugas yang harus dikerjakan oleh guru, yaitu sebagai pengelola pembelajaran dan sebagai pengelola kelas. Perekrutan guru dan pemilihan guru tahsin yang dilakukan pihak SDIT Khaira Ummah sudah tepat, karena terbukti para pengajar tahsin yang terpilih sangat berkomitmen menjalankan berbagai program yang telah dicanangkan oleh sekolah, khususnya dalam pembelajaran tahsin dan tahfiz al-Qur'an dengan menggunakan metode talaqqi.

Adapun untuk pengaturan siswa, pihak sekolah mengeluarkan kebijakan khusus untuk pembelajaran tahsin dan tahfiz al-Qur'an dalam satu rombel dibagi menjadi 2 atau 3 kelompok. Setiap kelompok rata-rata terdiri dari 7 sampai 10 orang. Hal ini dimaksudkan agar dalam proses pembelajaran menjadi lebih maksimal karena guru dapat mengontrol, mengawasi serta melihat perkembangan setiap siswa secara langsung dan lebih terfokus. Untuk teknis pembagian atau pengelompokkan siswa dipilih berdasarkan hail test yang di lakukan oleh koordinator tahsin. Setiap kelas biasanya dibagi menjadi 3 kelompok, yaitu: kelompok A, untuk siswa-siswi tingkatan lancar membaca al-Qur'an, kelompok B, untuk siswa-siswi dengan kemampuan kurang lancar membaca al-Qur'an, dan kelompok C, untuk siswa-siswi tingkatan pemula (dasar).

Siswa merupakan komponen inti dari pembelajaran, tehnik pengelompokkan dimaksudkan agar guru dapat lebih mudah melakukan pengawasan terhadap perkembangan kemampuan siswa dalam membaca al-Qur'an, sehingga apabila ada seorang siswa yang bermasalah akan mendapat penanganan yang cepat dari yang bersangkutan. Namun yang harus diperhatikan adalah jumlah siswa dalam satu kelompok tidak boleh terlalu banyak atau maksimal 10 siswa perkelompok. Semakin sedikitjumlah siswa dalam setiap kelompok akan semakin mudah pula bagi guru untuk mengimplementasikan metode talaqqi dalam pembelajaran tahsin dan tahfiz al-Qur'an, karena metode talaqqi harus adalah bagaimana caranya supaya siswa dapat mencontohkan bacaan al-Qur'an dengan benar sesuai dengan apa yang dicontohkan guru, sehingga jumlah siswa yang terlalu banyak dalam satu kelompok akan berpengaruh terhadap proses evaluasi secara individual di akhir pembelajaran yang kurang maksimal (Anshori, 2014). 
Dalam desain pengaturan waktu, pelaksanaan pembelajaran tahsin dan tahfiz al-Qur'an dilaksanakan 4 kali dalam satu minggu, yaitu setiap hari Senin sampai Kamis, waktu pelaksanaannya adalah setelah solat duha berjamaah sampai istirahat pertama atau dimulai sekitar jam 08.20 sampai jam 09.30, waktu tersebut dihitung 2 jam pelajarana tau 2 X 35 menit. Pembelajaran tahsin dan tahfiz al-Qur'an merupakan salah satu pelajaran preioritas di SDIT Khaira Ummah Tanjungsari, sehingga pemilihan waktu pelajaran pun lebih di utamakan dibanding dengan beberapa pelajaran lain. Dengan diberikannya intensitas waktu yang cukup lama serta pemilihan waktu yang strategis dipagi hari. Pembelajaran tahsin dan tahfiz al-Qur'an ini diharafkan proses pembelajarannya menjadi lebih maksimal, karena kondisi siswa masih segar fikirannya maupun kondisi fisiknya dan semangat mereka untuk belajar juga masih tinggi.

Pemilihan waktu belajar merupakan salah satu hal yang penting demi tercapainnya tujuan pembelajaran khususnya pembelajaran tahsin dan tahfiz al-Qur'an di SDIT Khaira Ummah Tanjungsari. Dengan dilaksanakannya pembelajaran tahsin dan tahfiz al-Qur'an dipagi hari, diharafkan proses pembelajarannya menjadi lebih maksimal, karena fikiran siswa maupun kondisi fisiknya masih segar dan semangat siswa untuk belajar juga masih tinggi.

Adapun untuk tempat pembelajaran tahsin dan tahfiz al-Qur'an dengan metode talaqqi menggunakan sistem moving class. Salah satu alasan diterapkannya sistem moving class ini adalah untuk mengantisifasi ketersediaan jumlah kelas, karena dengan diterapkannya sistem belajar perkelompok, kebutuhan akan tempat belajar menjadi 3x lipat, sesuai dengan jumlah setiap rombel rata-rata dibagi menjadi 3 kelompok. Selain itu dengan sistem moving class dimaksudkan agar siswa mendapat pengalaman yang berbeda dalam pembelajaran, hal ini disebabkan karekteristik dan sifat anak-anak usia SD yang terkadang cepat merasa jenuh dan bosan dalam mengikuti pelajaran.

Tempat belajar merupakan hal yang penting untuk keberlangsungan pembelajaran. Kondisi tempat yang tidak sesuai akan mempengaruhi kualitas pembelajaran. Sistem moving class sebagai salah satu upaya yang dilakukan pihak SDIT Khaira Ummah untuk menciptakan suasana belajar yang baru patut diapresiasi. Namun ada beberapa hal yang harus diperhatikan, dalam penerepan sistem moving class mental pengajar dan siswa harus siap mengahadapi segala konsekuensi yang diterapkan dalam sistem ini, misalnya seorang guru harus mampu memanfaatkan lingkungan sekitar sebagai sumber belajar serta bersedia memaksimalkan berbagai media pembelajaran yang disesuaikan dengan lingkungan pembelajaran di dalam maupun di luar kelas. Selain itu siswa juga harus berkomitmen mengikuti pembelajaran dengan tertib dan tidak tergoda untuk bermain-main ketika pembelajaran tahsin dan tahfiz al-Qur'an yang dilaksanakan di alam terbuka atau di luar kelas.

Desain pemilihan materi ajar tahsin dan tahfiz al-Qur'an disesuaikan dengan tingkat perkembangan peserta didik dengan rata-rata usia SD antara 6-13 tahun, sehingga materi yang disajikan bahasannya tidak terlalau berat serta mudah dipahami oleh anak-anak, konten serta tampilannya menarik sehingga siswa menjadi mudah mengerti dan menikmati proses pembelajaran. Dalam praktiknya materi pembelajaran al-Qur'an di SDIT Khaira Ummah Tanjungsari dibagi menjadi 4 tingkatan, yaitu: Pertama, tingkatan pemula untuk kelas 1. Kedua, tingkatan pra tahsin untuk kelas 2. Ketiga, tingkatan tahsin untuk kelas 3 sampai kelas 6 dan Keempat, tahfiz al-Qur'an yang diperioritaskan untuk kelas 3 sampai kelas 6.

Materi pembelajaran menempati posisi yang sangat penting dari keseluruhan kurikulum yang harus dipersiapkan agar pelaksanaan pembelajaran dapat mencapai sasaran. Pemilihan bahan dan materi pembelajaran tahsin dan tahfiz al-Qur'an di SDIT Khaira Ummah Tanjungsari sudah sangat pas, karena menyesuaikan dengan tingkat perkembangan usia anak SD, sehingga materi yang disajikan sangat menarik dan materi pembelajaran disusun secara sistematis dengan mengikuti prinsip psikologi. 
Pelaksanaan pembelajaran tahsin dan tahfiz al-Qur'an dengan menggunakan metode talaqqi di kelas 3 SDIT Khaira Ummah Tanjungsari. Pelaksanaan pembelajaran tahsin dan tahfiz al-Qur'an di SDIT Khaira Ummah Tanjungsari secara umum mengklasifikasikan menjadi empat marhalah (tingkatan), yaitu tingkatan pemula untuk kelas 1 , pembelajaran pratahsin untuk kelas 2, pembelajaran tahsin untuk kelas 3 dan pembelajaran tahfiz untuk kelas 3 sampai kelas 6, adapun dari kelas 1 juga sudah dibiasakan untuk menghafal surat-surat pendek tetapi tidak menjadi perioritas.

Kebijakan sekolah yang membagi pembelajaran al-Qur'an menjadi empat marhalah sudah tepat, karena proses pembelajaran al-Qur'an bagi siswa menjadi lebih terarah, jelas tahapan-tahapan yang harus dilaluinya sesuai dengan levelnya, serta setiap marhalah memiliki indikator pencapaian yang telah disesuaikan. Karena metode yang digunakan di SDIT Khaira Ummah Tanjungsari adalah metode talaqqi, sehingga terget bagi siswa tidak hanya dapat membaca al-Qur'an saja, tetapi membacanya harus benar sesuai dengan yang dicontohkan guru dengan mengikuti kaidah ilmu tajwid (Kurnaedi, 2014). Jadi bagi siswa yang sudah bisa membaca al-Qur'an di kelas 1, akan tetap diberikan materi dasar atau pemula, karena penyampaian materi melalui proses talaqqi oleh seorang guru yang bersertifikat dari lembaga tahsin. Dalam pembelajaran tahfiz di SDIT Khaira Ummah Tanjungsari, siswa tidak hanya dituntuk untuk menghafal banyak ayat atau surat, tetapi lebih ditekankan pada kualitas hafalan. Yaitu siswa tidak hanya hafal, melainkan bacaan surat yang dihafalnya sesuai dengan kaidah tahsin.

Adapun pelaksanaan pembelajaran tahsin dan tahfiz al-Qur'an dengan menggunakan metode talaqqi di kelas 3 SDIT Khaira Ummah Tanjungsari di bagi kedalam 3 kelompok, yaitu kelompok A untuk siswa dengan kategori mahir (lancar membaca al-Qur'an dan rata-rata hafal juz 30), kelompok B untuk siswa dengan kategori kurang lancar (bisa membaca al-Qur'an tapi tingkat kesalahannya masih cukup banyak) dan kelompok C untuk siswa dengan kategori dasar (terbata-bata dalam membaca al-Qur'an) (Az-Zawawi, 2010).

Pihak sekolah memberikan indikator pencapaian yang berbeda-beda untuk setiap kelompoknya, hal ini karena tidak setiap siswa di kelas 3 memiliki kemampuan yang merata dalam membaca maupun menghafal al-Qur'an. Misalnya indikator pencapaian pembelajaran tahsin untuk kelompok C adalah siswa mampu membaca al-Qur'an, sedangkan indikator pencapaian kelompok B dan kelompok A adalah siswa mampu membaca al-Qur'an serta terbebas dari berbagai macam kesalahan dalam membaca al-Qur'an (kesalahan jaly dan khafy). Adapun indikator pembelajaran tahfiz al-Qur'an untuk kelas $\mathrm{C}$ hanya sebatas hafal saja beberapa surat pendek, sementara penggunaan kaidah tajwid belum terlalu di tekankan, karena siswa di kelimpok $\mathrm{C}$ rata-rata masih terbata-bata dalam membaca al-Qur'an.

Pada umumnya pelaksanaan pembelajaran tahsin dan tahfiz al-Qur'an dengan menggunakan metode talaqqi di kelas 3 SDIT Khaira Ummah Tanjungsari dimulai dengan kegiatan pra pembelajaran, kegiatan pembuka, kegiatan inti dan kegiatan penutup. Dalam metode talaqqi ini biasanya dilakukan secara jama'i (klassikal) yaitu seorang guru mencontohkan bacaan di depan para siswa dalam satu kelompok dan setelah menyimak bacaan guru kemudian siswa diminta untuk menirukan bacaan yang dicontohkan oleh guru. Tehnik lainnya biasanya dilakukan secara private (individual) yaitu seorang peserta didik berhadapan langsung dengan guru, supaya dapat diketahui bagaimana kemampuan siswa satu-persatu. Adapun waktu pelaksanaan pembelajaran tahsin dan tahfiz al-Qur'an adalah 2x35 menit, yakni pelaksanaannya dilakukan dalam satu waktu. Biasanya untuk materi tahfiz difokuskan di 35 menit pertama, yaitu dengan muroja'ah surat-surat yang telah dihafal dan talaqqi surat baru. Setelah itu baru pemaparan materi tahsin di 35 menit kedua.

Pelaksanaan pembelajaran tahsin dan tahfiz al-Qur'an dengan menggunakan metode talaqqi di kelas 3 SDIT Khaira Ummah Tanjungsari sangat penting untuk diperhatikan, karena kelas 3 merupakan 
tolak ukur berhasil tidaknya pelaksanaan pembelajaran pada tingkat sebelumnya, yaitu pembelajaran tingkat pemula yang dilaksanakan di kelas 1 dan pembelajaran pra tahsin yang dilaksanakan di kelas 2 . Apabila pada pelaksanaan di dua tahap sebelumnya seorang siswa mengalami banyak hambatan, bisa dipastikan siswa tersebut akan sulit menyesuaikan dengan pembelajaran tahsin di kelas 3. Oleh sebab itu di kelas 3 sangat mendapat perhatian, karena seorang siswa tidak akan mungkin kelasnya tidak dinaikkan karena pembelajaran tahsin yang tidak memenuhi indikator pencapaian. Sehingga bagi setiap siswa kelas 3 benar-benar akan di bekali dengan ilmu dasar tahsin sampai siswa benar-benar faham, karena di kelas 4, 5 dan juga kelas 6 ada pula pembelajaran tahsin, namun dengan muatan materi yang lebih berat dari materi tahsin yang disampaikan di kelas 3. Bagi seorang siswa yang belum lancar dalam tahsin dapat menghambat juga kepada pembelajaran tahfiz al-Qur'an, karena syarat di perbolehkannya menghafal alQur'an di SDIT Khaira Ummah Tanjungsari adalah harus sudah dinyatakan lulus pada pembelajaran tahsin.

Evaluasi pembelajaran tahsin dan tahfiz al-Qur'an dengan menggunakan metode talaqqi di kelas III SDIT Khaira Ummah Tanjungsari. Ruang lingkup penilaian dalam implementasi metode talaqqi pada pembelajaran tahsin dan tahfiz al-Qur'an di kelas 3 SDIT Khaira Ummah Tanjungsari mencakup pengujian terhadap hasil belajar peserta didik pada aspek kognitif, afektif, dan psikomotor. Bentuk penilaiannya terdiri atas beberapa jenis tagihan, yaitu; kuis, pertanyaan lisan, tugas individu, responsi atau ujian praktik, ulangan harian dan lain-lain.

Dalam satu semester dilaksanakan tiga tahap penilaian, yaitu penilaian ulangan harian, penilaian mid semester (UTS) dan penilaian akhir smester (UAS). Adapun untuk laporan hasil belajar, sesuai dengan program yang telah dicanangkan, SDIT Khaira Ummah Tanjungsari melaporkan hasil belajar siswa sebanyak tiga kali dalam satu semester. satu kali berupa laporan hasil belajar ulangan harian (UH) satu kali hasil Ujian Tengah Semester, dan sekali berupa profil hasil belajar semester yang terangkum dalam Raport Semester. Nilai Raport Semester merupakan rangkuman nilai dari hasil tagihan (ulangan harian, UTS, UAS, tugas-tugas, dan nilai-nilai lainnya) selama semester berlangsung. Laporan hasil belajar merupakan suatu kewajiban bagi sekolah untuk melaporan hasil belajar peserta didiknya kepada orang tua atau wali dalam jangka waktu tertentu. Hal ini dimaksudkan agar mereka mengetahui prestasi akademik, perkembangan kepribadian, dan kompetensi yang telah dicapai siswa selama kurun waktu belajar. Dengan harapan agar turut berpartisipasi dalam melakukan pembinaan dan pengawasan terhadap perkembangan belajar siswa.

Adapun proses evaluasi pembelajaran tahsin dan tafizh al-Qur'an di kelas 3 SDIT Khaira Ummah Tanjungsari sudah sesuai prosedur dan tersusun secara sistematis, sehingga diharafkan akan mampu meningkatkan pencapaian siswa dalam pembelajaran al-Qur'an.

Berdasarkan hasil evaluasi Ujian Akhir Semester, perkembangan pada kelompok A mengalami kemajuan yang cukup signifikan, hal ini dibuktikan dengan nilai yang diperoleh oleh siswa sangat bagus atau diatas rata-rata dan telah memenuhi indikator pencapain pembelajaran tahsin dengan di kuasainya materi : Isti'adzah dan Basmalah, konsistensi tanda panjang, keseimbangan tanda ghunnah, tuntutan kesempurnaan vokal, pengucapan huruf sakinah. Adapun indikator pembelajaran tahfiz al-Qur'an untuk kelas 3 adalah hafal surat al-A'la sampai surat at-Takwir, namun tidak sedikit siswa di kelompok A yang sudah hafal juz 30.

Berdasarkan hasil observasi dan wawancara, bahwasannya kemajuan di kelompok A dalam pembelajaran tahsin dan tahfiz al-Qur'an dengan metode talaqqi ini tidak terlepas dari berbagai faktor pendukung, diantaranya latar belakang siswa yang sudah bisa membaca al-Qur'an dan terbiasa menghafal al-Qur'an sebelum usia SD, semangat dan motivasi belajar siswa yang tinggi, faktor bimbingan orang tua, 
serta atas bimbingan pengajar tahsin yang menggunakan berbagai variasi tehnik mengajar dalam pembelajaran tashin dan tahfiz al-Qur'an dengan metode talaqqi.

Adapun untuk kelompok B berdasarkan hasil evaluasi di akhir semester cukup bagus dan mengalami kemajuan. Tercapainya KKM bagi siswa menjadi salah satu bukti berhasilnya kegiatan pembelajaran tahsin dan tahfiz al-Qur'an dengan metode talaqqi di kelompok B. Siswa juga mampu memenuhi target indikator pencapaian. Kemampuan siswa dalam membaca al-Qur'an banyak mengalami kemajuan, siswa mampu memperbaiki bacaan al-Qur'an dan meminimalisir berbagai macam kesalahan dalam membaca al-Qur'an. Sementara dalam pembelajaran tahfiz al-Qur'an siswa mampu menghafal surat al-A'la sampai surat at-Takwir sesuai dengan indikator pencapaian yang telah di tetapkan dalam pembelajaran tahfiz al-Qur'an oleh pihak sekolah.

Kelompok C merupakan kelompok yang mendapat perhatian lebih dari pihak sekolah pada pembelajaran tahsin dan tahfiz al-Qur'an di kelas 3. Hal ini cukup beralasan, mengingat kemampuan siswa pada kelompok ini di bawah rata-rata siswa pada kelompok yang lain, sehingga diperlukan penanganan khusus untuk membina siswa-siswa di kelompok C agar mampu membaca al-Qur'an. Dalam menetapkan indikator pencapaian pihak sekolah juga tidak terlalu banyak target sperti di kelompok-kelompok lain di kelas 3. Siswa kelompok C diberi target agar bisa membaca al-Qur'an langsung dari mushafnya, tidak seperti pada tingkat pembelajaran sebelumnya yaitu tingkat pemula dan pratahsin yang menggunakan modul pembelajaran dan belum di tekankan belajar membaca al-Qur'an langsung dari mushafnya. Dalam pembelajaran tahfiz al-Qur'an pun indikator pencapaian untuk kelompok $\mathrm{C}$ hanya ditargetkan agar bisa hafal surat-surat pendek di juz 30.

Adapun berdasarkan hasil evaluasi di akhir semester untuk kelompok C secara umum belum memenuhi KKM untuk kelas 3. Akan tetapi apabila dilihat dari indikator yang telah ditetapkan untuk kelas C, sebagian siswa pada kelompok ini telah mengalami beberapa kemajuan. Contohnya adalah 3 dari 10 siswa pada kelompok $\mathrm{C}$ sudah menyelesaikan pembelajaran pada modul tahsin, sehingga sudah di izinkan untuk belajar membaca al-Qur'an dari mushafnya. Sementara untuk yang 7 siswa masih harus mendapat perhatian lagi.

Berdasarkan wawancara dan observasi yang dilakukan di kelompok C, dapat diketahui beberapa faktor penghambat maupun permasalahan dalam pembelajaran tahsin dan tahfiz al-Qur'an secara garis besar disebabkan berdasarkan 2 faktor, yaitu faktor guru dan faktor siswa. Diantara permasalahan dari faktor guru adalah: pengelolaan kelas yang kurang kondusif, kurangnya variasi tehnik yang digunakan dalam metode talaqqi, kurang mampu memonitoring kemampuan siswa, komunikasi yang kurang baik antar pengajar tahsin dan tahfiz al-Qur'an, faktor menejemen waktu dan lemahnya komunikasi dengan orang tua atau wali murid. Adapun beberapa permasalahan dari faktor siswa diantaranya: faktor latar belakang siswa, semangat siswa yang naik turun, faktor daya serap siswa (kemampuan kognitif), siswa kurang konsentrasi terhadap materi tahsin dan tahfiz al-Qur'an, perbedaan cara belajar antar individu siswa serta faktor kedisiplinan siswa.

Berdasarkan pelaksanaan kegiatan pembelajaran tahsin dan tahfiz al-Qur'an dengan menggunakan metode talaqqi di kelas 3 SDIT Khaira Ummah Tanjungsari, secara garis besar dapat disimpulkan tidak terlepas dari faktor penghambat dan pendukung. Faktor pendukung tentu saja menjadi dampak positif dalam pembelajaran tahsin dan tahfiz al-Qur'an, sedangkan faktor penghambat harus bisa diatasi dan dicari solusi yang tepat untuk mengatasinya agar tidak mengganggu proses pembelajaran.

Kelas 3 SDIT Khaira Ummah Tanjungsari, dalam implementasi metode talaqqi pada pembelajaran tahsin dan tahfiz al-Qur'an terdapat beberapa faktor pendukung: 


\section{Faktor kebijakan sekolah}

Pembelajaran tahsin dan tahfiz al-Qur'an merupakan salah satu mata pelajaran yang mendapat perhatian khusus serta menjadi perioritas utama di SDIT Khaira Ummah Tanjungsari. Hal ini dibuktikan dengan memberikan waktu yang seluas-luasnya untuk pembelajaran tahsin dan tahfiz al-Qur'an, yaitu mulai dari hari Senin sampai dengan hari Kamis, bahkan pihak sekolah menempatkan jadwal pembelajaran tahsin dan tahfiz al-Qur'an di pagi hari, yaitu setelah pelaksanaan solat Dhuha.

Guna meningkatkan kulitas para pengajar tahsin dan tahfiz al-Qur'an, pihak sekolah juga mewajibkan setiap guru tahsin untuk mengikuti pembinaan tahsin serta up greding metode talaqqi yang biasa diadakan setiap pertengahan bulan, sehingga keterampilan dan kemampuan para pengajar diharafkan akan semakin berkembang.

\section{Faktor sarana dan prasarana}

Sarana prasarana di SDIT Khaira Ummah Tanjungsari termasuk lengkap, hal ini memudahkan pelaksanaan implementasi metode talaqqi pada pembelajaran tahsin dan tahfiz al-Qur'an. Ruang kelas yang memadai, halaman sekolah yang luas, gazebo atau saung yang dibuat khusus untuk pembelajaran tahsin dan tahfiz bagi siswa, serta terdapatnya mesjid sebagai pusat kegiatan keagamaan siswa sangat menunjang terlaksananya pembelajaran tahsin dan tahfiz al-Qur'an. Dengan sarana prasarana yang memadai memudahkan guru dalam menerapkan atau melaksanakan pembelajaran tahsin dan tahfiz alQur'an dengan metode talaqqi.

\section{Faktor masyarakat dan lingkungan sekitar}

Respon masyarakat sekitar sangat baik dan menyambut hangat dengan hadirnya SDIT Khaira Ummah di lingkungan mereka. Hal ini terbukti ketika para siswa memilih halaman rumah maupun mesjid milik masyarakat sekitar untuk dijadikan sebagai tempat belajar al-Qur'an. Para pengajar tahsin dan tahfiz al-Qur'an sangat terbantu dengan keramahan masyarakat sekitar, sehingga proses pembelajaran tahsin dan tahfiz al-Qur'an yang menggunakan sistem moving class bisa terlaksana dengan baik tanpa adanya kendala mengenai tempat.

\section{Faktor lokasi sekolah}

Lokasi sekolah yang berada di daerah perbukitan, beriklim sejuk serta tidak terlalu dekat dan juga tidak terlalu jauh dengan pusat kota membuat suasana belajar menjadi lebih kondusif, terutama dalam pembelajaran tahfiz al-Qur'an, sehingga diharafkan para siswa bisa lebih maksimal dalam menghafal alQur'an dengan metode talaqqi.

\section{Faktor Peserta didik}

Peserta didik kelas 3 SDIT Khaira Ummah Tanjungsari memiliki respon yang baik dalam pembelajaran tahsin dan tahfiz al-Qur'an. Hal ini memudahkan guru tahsin dan tahfiz al-Qur'an untuk menerapkan metode talaqqi dalam proses pembelajarannya.

Adapun permasalahan- permasalahan dalam implementasi metode talaqqi pada pembelajaran tahsin dan tahfiz al-Qur'an diantaranya yaitu ada yang bersumber dari pengajar dan ada juga bersumber dari siswa. Adapun penjelasannya berdasarkan hasil observasi peneliti yaitu sebagai berikut:

Permasalahan- permasalahan dalam implementasi metode talaqqi pada pembelajaran tahsin dan tahfiz al-Qur'an yang bersumber dari faktor pengajar tahsin dan tahfiz alQur'an, berikut penjelasan beserta alternatif solusinya

\section{Terbatasnya jumlah pengajar tahsin}

Pengajar tahsin di SDIT Khaira Ummah Tanjungsari merupakan para pengajar yang telah mengikuti proses seleksi serta menjalani serangkaian test yang diadakan oleh koordinator tahsin terlebih 
dahulu, sehingga tidak setiap guru yang ada di SDIT Khaira Ummah diberi kesempatan untuk menjadi pengajar tahsin dan tahfiz al-Qur'an. Sehingga hal ini berpengaruh terhadap ketersediaan jumlah pengajar tahsin. Hingga akhirnya untuk menutupi kekurangan jumlah kelompok siswa yang harus segera mendapat pengajar tahsin, secara terpaksa pihak sekolah meloloskan beberapa guru yang belum masuk kepada kriteria pengajar tahsin yang diharafkan. Adapun kriteria untuk calon pengajar tahsin berdasarkan ketetapan sekolah adalah dapat membaca al-Qur'an dengan baik dan benar serta pernah mengikuti talaqqi atau pembinaan tahsin, biasanya dibuktikan dengan ijazah atau syahadah.

Adapun alternatif solusinya pihak sekolah dapat mengeluarkan kebijakan bagi semua guru untuk mengikuti pembinaan tahsin dengan tutor khusus atau pengajar yang didatangkan dari lembaga tahsin. Kebijakan ini di perioritaskan bagi guru-guru lulusan PT (perguruan tinggi) Agama Islam. Karena pada hakikatnya tahsin tidak hanya wajib dipelajari bagi calon pengajar al-Qur'an saja, tetapi setiap muslim. Setelah hampir semua guru di SDIT Khaira Ummah Tanjungsari melakukan pembinaan tahsin, pihak sekolah bisa menyeleksi kembali guru-guru tersebut untuk di pilih menjadi pengajar tahsin sesuai dengan kriteria yang dibutuhkan oleh sekolah.

\section{Kurangnya variasi tehnik yang digunakan dalam metode talaqqi}

Metode talaqqi merupakan salah satu metode yang cocok digunakan untuk semua kalangan, termasuk untuk usia anak SD, namun hal yang harus menjadi perhatian lebih salah satunya adalah bahwa anakSD merupakan tipe pembelajar yang terkadang mudah bosan dan selalu menginginkan terhadap halhal yang baru. Adapun pembelajaran tahsin dan tahfiz al-Qur'an dilaksanakan dengan sistem moving class, sehingga guru harus pandai memilih penggunaan media pembelajaran yang sesuai dengan tingkat perkembangan usia peserta didik.

Pada dasarnya pengajaran dengan metode talaqqi adalah sama, yaitu bisa dilakukan secara klasikal maupun individual. Untuk mengatasi permasalahan kurangnya variasi tehnik dalam mengajar al-Qur'an, pihak sekolah dapat mengeluarkan kebijakan dengan melakukan super visi bagi seluruh pengajar tahsin, agar dapat dicarikan solusinya secara bersama-sama. Selain itu pihak sekolah juga dapat membantu menyediakan berbagai media pembelajaran yang dibutuhkan dalam pembelajaran tahsin dan tahfiz alQur'an. Sehingga hal ini diharafkan dapat mendorong bagi guru-guru yang merusa kurang dalam variasi tehnik mengajar dengan metode talaqqi agar terus berkembang.

\section{Pengelolaan kelas yang kurang kondusif}

Penerapan sistem moving class dalam pembelajaran tahsin dan tahfiz al-Qur'an cukup meningkatkan antusias siswa, namun disisi lain, usia anak SD merupakan usia dimana mereka sedang asik-asiknya dalam bermain, sehingga tidak sedikit banyak waktu yang terbuaang sia-sia karena siswa lebih banyak bermainnya dibanding dengan belajar, karena sebagian besar kegiatan pembelajaran dilaksankan diluar kelas bahkan diluar lingkungan sekolah.

Usia anak SD merupakan usia dimana mereka sedang asik-asiknya bermain. Mengajar pada tingkat SD, seorang guru dituntut agar lebih memahami lagi dunia anak-anak. Suasana belajar jangan terlalu serius supaya siswa tidak tegang dalam belajar al-Qur'an. Agar suasana kelas menjadi kondusif salah satu kuncinya adalah harus bisa mengendalikan siswa. Hal ini bisa dilakukan dengan diberlakukannya reward and punishment (hadiah dan hukuman). Guru dapat mengiming-iming siswa dengan membeikan hadiah bagi siswa yang tertib dan mengikuti semua aturan, contohnya bisa dengan membagikan tanda bintang bagi siswa yang penurut, fungsi tanda bintang itu akan mengangkat moral siswa karena ia merasa dihargai. Adapun bagi siswa yang tidak tertib bisa diberikan hukuman, misalnya muroja'ah bacaan surat yang telah dihafal di dpan kelas. 


\section{Kurang mampu memonitoring kemampuan siswa.}

Setiap kelompok terdiri dari 7 sampai 10 orang siswa, bahkan dikelas lain ada yang lebih. Dan seorang guru tidak hanya fokus menagajar pada satu kelompok saja, melainkan harus mengajar kelompok yang lain juga karena terbatasnya jumlah pengajar tahsin dan tahfiz al-Qur'an. Sehingga perhatian guru terhadap siswa menjadi terbagi-bagi dalam hal monitoring kemampuan siswa, terutama mengenai kemampuan siswa dalam membaca al-Qur'an.

Seorang guru minimal wajib hafal nama-nama siswa yang belajar dalam kelompoknya. Dan melakukan berbagai pendekatan kepada siswa, sehingga apabila terdapat siswa yang bermasalah dan tidak mencapai indikator pencapaian dalam pembelajaran tahsin dan tahfiz al-Qur'an, guru tidak langsung menyalahkan siswa atau menganggap siswa tidak pintar atau pemalas, melainkan diselidiki apa penyebabya, sehingga peran seorang guru tdak hanya memonitoring aspek kognitifnya saja, melainkan harus semuanya mencakup aspek psikomotor dan aspek afektif siswa.

\section{Komunikasi yang kurang baik antar pengajar tahsin dan tahfiz al-Qur'an.}

Di SDIT Khaira Ummah Tanjungsari Terdapat 13 orang pengajar tahsin dan tahfiz al-Qur'an. Setiap pengajar bertanggung jawab kepada satu kelompok tahsin. Namun ketika satu guru berhalangan untuk hadir, maka kelompok yang menjadi tanggung jawabnya menjadi terabaikan, ketika tugasnya diganti dengan guru yang lain, tidak ada konfirmasi mengenai kelompok tersebut, baik mengenai materi yang sedang dibahas maupun hal-hal yang berkaitan dengan siswa pada kelompok tersebut. Dan ketika digabung dengan kelompok lain suasana pembelajaran menjadi tidak kondusif karena jumlah siswa bartambah menjadi dua kali lipat pada kelompok tersebut dan guru menjadi semakinn sulit untuk mengkondisikan kelas.

Komunikasi sangat diperlukan bagi semua guru, termasuk guru tahsin dan tahfiz al-Qur'an. Dengan terjalinnya komunikasi yang baik permasalahan yang besar maupun yang kecil dapat ditangani bersama, terutama mengenai berbagai masalah yang berhubungan dengan siswa dalam pembelajaran tahsin dan tahfiz al-Qur'an. Dalam hal ini seorang koordinator tahsin harus berperan. Bagi semua guru tahsin wajib melaporkan hasil pembelajaran tahsin kepada koordinator, minimal sampai mana penyampaian materi yang disampaikan dan hal penting apa saja yang terjadi pada hari itu dalam pembelajaran tahsin dan tahfiz al-Qur'an. Dan ketika ada guru yang berhalangan tidak hadir, wajib konfirmasi kepada koordinator minimal satu hari sebelum ia ijin, supaya bisa segera ditentukan penggantinya dan guru yang bersangkutan dapat mempersiapkan bahan materi ajar maupun media pembelajaran sesuai dengan pembahasan materi pada hari tersebut.

\section{Manajemen Waktu}

Metode talaqqi dalam pembelajaran al-Qur'an menuntut seorang guru agar banyak memberikan contoh bacaan yang benar dan fasih dalam membacakan ayat-ayat al-Qur'an, sehingga terkadang tidak cukup hanya mencontohkan satu kali dalam pembacaan ayat-ayat al-Qur'an, bahkan harus dilakukan secara berulang-ulang sampai siswa benar-benar mampu menirukan apa yang dibaca oleh guru. Hal ini membutuhkan waktu yang tidak sedikit, bahkan proses setoran hafalan siswa maupun evaluasi bacaan atau tilawah siswa dengan cara talaqqi juga tidak bisa dilaksanakan secara maksimal, karena berbenturan dengan waktu istirahat atau jadwal pelajaran berikutnya (Hanapi, 2014).

Menejemen waktu merupakan hal yang penting untuk diperhatikan oleh setiap pengajar tahsin, karena suksesnya pembelajaran tahsin salah satunya ditentukan juga bagaimana cara seorang guru mengatur waktu selama proses pembelajaran. Pihak SDIT Khaira Ummah memberikan waktu 2 jam pelajaran atau 2x35 menit perharinya untuk pembelajaran tahsin dan tahfiz al-Qur'an. Seorang guru tahsin dan tahfiz minimal harus punya persiapan dan strategi sebelum mengajar di kelas yang biasanya 
terdapat RPP. Sehingga kegiatan pembelajaran tidak berjalan begitu saja, tetapi sudah terkonsep mengenai kegiatan yang akan dilakukan di dalam kelas, termasuk estimasi waktu untuk kegiatan pembuka, kegiatan inti dan kegiatan penutup dalam pembelajaran tahsin dan tahfiz al-Qur'an.

\section{Lemahnya komunikasi dengan orang tua atau wali murid}

Pembelajaran tahsin dan tahfiz merupakan salah satu mata pelajaran yang diadakan oleh SDIT Khaira Ummah Tanjungsari, sehingga pihak sekolah hanya membantu memfasiltasi berdasarkan kemampuan sekolah. Namun pada kenyataannya banyak komplain dari pihak wali murid mengenai kemampuan anaknya dalam membaca al-Qur'an yang kurang berkembang dan terlihat tidak banyak kemajuannya.

Siswa merupakan tanggung jawab bersama. Pembelajaran al-Quran tidak bisa dilakukan oleh salah satu pihak saja bahkan saling mengandalkan atau berjalan sendiri-sendiri baik itu dilakukan oleh guru di sekolah maupun oleh wali murid di rumah. Bisa tidaknya siswa dalam membaca dan menghafal al-Qur'an bukan hanya tugas guru-guru disekolah saja, melainkan tugas bersama dengan wali murid untuk melaksanan pengawasan dan bimbingan kepada siswa, oleh sebab itu harus adanya saling pengertian (Badwilan, 2011). Pola komunikasi harus dibangun sebaik mungkin dengan berbagai pihak, terutama dengan pihak wali murid. Karena suksesnya pembelajaran tahsin dan tahfiz ditentukan juga bagaimana pengawasan kepada siswa ketika di luar sekolah, khususnya di rumah. Sebuah komunikasi bisa terjalin dengan berbagai jalan, apabila tidak memungkinkan untuk bertemu secara langsung dengan wali murid, melalui pesan singkat atau telepon juga bisa menjadi alternatif, yang terpenting adalah adanya komunikasi antara pengajar dan wali murid supaya bisa sama-sama membimbing dan mengawasi siswa baik ketika berada di sekolah maupun di rumah.

\section{Permasalahan- permasalahan dalam implementasi metode talaqqi pada pembelajaran tahsin dan tahfiz al-Qur'an yang bersumber dari faktor siswa, berikut penjelasan beserta alternatif solusinya:}

\section{Latar belakang siswa yang belum pernah mendapat pendidikan al-Qur'an.}

Seorang siswa dengan latar belakang keluarga dan lingkungan yang agamis bisanya ketika masuk sekolah mereka sudah bisa membaca al-Qur'an bahkan tidak sedikit pula yang sudah memiliki bekal hafalan al-Qur'an, hal ini tidak lain karena mereka telah mendapat pendidikan agama yang cukup sebelum masuk sekolah. Namun pada kenyataannya tidak sedikit pula siswa-siswa yang masuk ke SDIT Khaira Ummah Tanjungsari memiliki latar belakang agama yang kurang kuat, bahkan belum pernah diajarkan membaca al-Qur'an di rumahnya, sehingga siswa sama sekali tidak bisa membaca al-Qur'an bahkan buta huruf Arab. Dan bagi siswa yang kemampuannya di bawah rata-rata akan menghambat proses pembelajaran di kelas maupun di kelompoknya, karena siswa tersebut harus mendapat perhatian lebih dari gurunya, sementara teman-temannya yang lain harus segera meneruskan materi selanjutnya, waktu pembelajaran menjadi kurang efektif karena banyak dihabiskan untuk fokus membimbing anak tersebut.

Setiap siswa yang masuk pada suatu instansi pendidikan pasti meliki latar belakang pengalaman pendidikan yang berbeda-beda, termasuk di SDIT Khaira Ummah Tanjungsari, tidak semua siswa sudah bisa membaca al-Qur'an, bahkan ada yang sama sekali belum mengenal huruf hijaiyah. Untuk mengatasi permasalahan tersebut pengajar tahsin perlu memberikan perlakuan khusus kepada siswa tersebut misalnya dengan mengatur tempat duduk agar berada pada posisi yang dekat dengan guru, sehingga siswa tersebut akan lebih fokus menerima materi yang disampaikan guru. Selain itu, guru juga harus berperan aktif mendorong kepada wali murid agar siswa di bimbing juga dalam membaca al-Qur'an ketika di rumah, sehingga pembelajaran al-Qur'an bagi siswa tidak hanya mengandalkan di sekolah saja. 


\section{Semangat siswa yang naik turun}

Pembelajaran tahsin dan tahfiz al-Qur'an dilaksanakan selama 4 hari dalam satu pekan, yaitu pada hari Senin, Selasa, Rabu dan Kamis. Terkadang bagi seorang siswa SD jenis pelajaran yang sama dan di ulang-ulang dapat membuat siswa menjadi jenuh dan mudah merasa bosan. Di hari Senin mungkin siswa masih semangat untuk belajar tahsin dan tahfiz al-Qur'an karena pada hari Jum'at tidak ada pelajaran tahsin dan tahfiz al-Qur'an, sementara pada hari Sabtu dan Ahad merupakan libur sekolah. Namun bagi sebagian siswa pada hari Rabu atau Kamis pembelajaran tahsin menjadi kurang berkesan bahkan biasa saja, karena turunnya semangat maupun motivasi belajar. Dengan turunnya semangat belajar tentu akan berdampak kepada hasil belajar siswa pada pembelajaran tahsin dan tahfiz al-Qur'an.

Sesuatu yang di ulang-ulang pasti dapat menimbulkan kebosanan, termasuk dalam pembelajaran tahsin dan tahfiz al-Qur'an di kelas 3 SDIT Khaira Ummah Tanjungsari yang dilaksanakan 4 kali dalam satu pekan. Guru memiliki kapasitas dan peranan yang besar dalam memotivasi siswa. Untuk meningkatkan motivasi siswa, pada kegiatan pendahuluan guru dapat melakukan permainan edukatif dengan berbagai gerakan interaktif dengan tujuan dapat merangsang otak siswa agak merespon terhadap pembelajaran tahsin dan tahfiz al-Qur'an. Guru juga dapat membangkitkan memotivasi siswa melalui kegiatan bercerita mengenai kisah inspiratif yang di ambil dari ayat-ayat al-Qur'an.

\section{Daya serap siswa yang berbeda-beda.}

Meskipun untuk pelakasanaan pembelajaran tahsin dan tahfiz al-Qur'an di bagi kepada kelompokkelompok berdasarkan test, namun pada kenyataannya pada setiap kelompok kemampuan siswa tidak seluruhnya merata. Hal ini membuat suasa pembelajaran di dalam kelompok menjadi tidak berimbang, karena ada siswa yang sangat dominan, namun ada pula siswa siswa yang pasif dalam pembelajaran tahsin dan tahfiz al-Qur'an.

Setiap siswa memiliki kemampuan kognitif yang berbeda-beda, sehingga ada yang cepat dalam menangkap pelajaran namun ada juga yang lambat. Seorang guru di tuntut agar lebih kreatif dalam penggunaan tehnik belajar yang disesuaikan dengan keadaan siswa, penggunaan media pembelajaran juga sangat dianjurkan agar penyampaian materi bisa diserap oleh seluruh siswa dalam pembelajaran tahsin dan tahfiz al-Qur'an dengan menggunakan metode talaqqi.

\section{Siswa kurang konsentrasi terhadap materi tahsin dan tahfiz al-Qur'an.}

Semangat dan motivasi siswa terhadap suatu pelajaran sangat mempengruhi kepada hasil belajar. Pada sebagian siswa di kelas 3 SDIT Khaira Ummah masalah konsentrasi belajar khusunya materi tahsin dan tahfiz al-Qur'an menjadi masalah utama, karena tidak sedikit siswa yang tidak tuntas memenuhi indikator pembelajaran tahsin dan tahfiz al-Qur'an.

Pelaksanaan pembelajaran tahsin dan tahfiz al-Qur'an yang dilaksanakan di alam terbuka atau di luar ruangan mungkin akan mengakibatkan kurangnya konsentrasi terhadap materi tahsin dan tahfiz alQur'an bagi sebagian siswa. Penggunaan media pembelajaran yang inovatif bisa menjadi salah satu solusi agar perhatian siswa terhadap materi tahsin lebih terfokus kembali. Selain itu penyajian materi tahsin juga harus dibuat lebih menarik, dengan cara penyampaian yang banyak melibatkan siswa dalam proses pembelajarannya.

\section{Perbedaan cara belajar antar individu siswa}

Penggunaan sistem moving class serta cara belajar kelompok pada pembelajaran tahsin dan tahfiz al-Qur'an di SDIT Khaira Ummah Tanjungsari tidak dapat dinikmati oleh semua siswa, karena ada sebagian siswa yang lebih senang belajar di ruangan dan tidak bisa belajar di ruang terbuka. Hal ini berhubungan dengan gaya belajar siswa yang lebih nyaman belajar pada suasana yang tenang dan kondusif ketika berada di dalam kelas. Pengelompokan siswa berdasarkan kemampuan membaca al- 
Qur'an juga berpengaruh bagi sebagian siswa, karena siswa A yang dekat dengan siswa B di kelas belum tentu satu kelompok, sehingga hal ini dapat mempengaruhi cara belajar siswa tersebut karena harus menyesuaikan dengan gaya belajar di kelompok tersebut.

Setiap siswa memiliki cara maupun gaya belajar tersendiri. Dan bagi sebagian siswa ada ketidak nyamanan ketika yang diterapkan adalah cara belajar dengan sistem kelompok. Yang pertama harus dilakukan guru adalah melakukan berbagai pendekatan kepada siswa tersebut. Selain itu guru juga harus bisa mendesain pembelajaran berkelompok agar lebih menarik, misalnya pemilihan lokasi belajar dan variasi tempat duduk denagan cara diatur sedemikan rupa agar seluruh siswa merasa nyaman dalam kelompok pembelajaran tahsin dan tahfiz al-Qur'an.

\section{Kurangnya disiplin siswa}

Kedisiplinan merupakann salah satu syarat bagi siswa untuk tercapainya tujuan pembelajaran. Namun sebagaian siswa kelas 3 SDIT Khaira Ummah ada yang kurang disiiplin ketika kegiatan pembelajaran tahsin dan tahfiz al-Qur'an sedang berlangsung, misalnya tidak mengikuti pembelajaran tahsin dan tahfiz al-Qur'an tanpa ada konfirmasi atau alasan yang jelas. datang terlambat dan pergi mendahului kelompok yang lain sebelum jadwal pembelajaran tahsin dan tahfiz selesai, jajan seblum waktu istirahat, mengganggu temannya yang lain baik dalam satu kelompok atau kepada kelompok lain.

Untuk mendisiplinkan siswa, terkadang seorang guru dituntut harus bersikap tegas kepada siapa saja yang melanggar aturan. Pemberlakuan reward and punishment (hadiah dan hukuman) bisa menjadi salah satu solusi. Sehingga bagi setiap siswa akan berfikir dahulu sebelum bertindak, karena apabila tindakannya salah ia akan mendapat hukuman dari guru, tapi sebaliknya apabila tindakannya sesuai aturan tentu iakan mendapat penghargaan atau sebuah hadiah dari gurunya.

Berdasarkan uraian diatas, dalam kegiatan pembelajaran tahsin dan tahfiz al-Qur'an dengan menggunakan metode talaqqi di kelas 3 SDIT Khaira Ummah Tanjungsari tidak terlepas dari faktor penghambat dan pendukung. Oleh sebab itu para guru dan kepala sekolah beserta jajaranya harus menjalin kerjasama yang baik agar penerapan metode talaqqi dalam pembelajaran tahsin dan tahfiz alQur'an berjalan dengan baik. Faktor pendukung tentu saja menjadi dampak positif dalam pembelajaran tahsin dan tahfiz al-Qur'an, sedangkan faktor penghambat harus bisa diatasi dan dicari solusi yang tepat untuk mengatasinya agar tidak mengganggu proses pembelajaran.

\section{SIMPULAN}

Desain pembelajaran tahsin dan tahfiz al-Qur'an dengan menggunakan metode talaqqi di SDIT Khaira Ummah Tanjungsari mencakup desain pengaturan guru, pengaturan siswa, pengaturan waktu dan tempat belajar serta desain materi ajar tahsin dan tahfiz al-Qur'an. Dalam pelaksanaan pembelajaran tahsin dan tahfiz al-Qur'an dengan metode talaqqi, secara umum SDIT Khaira Ummah Tanjungsari mengklasifikasikan menjadi empat marhalah (tingkatan), yaitu program pembelajaran pemula untuk kelas 1, pembelajaran pra tahsin untuk kelas 2, pembelajaran tahsin untuk kelas 3 sampai kelas 6 dan pembelajaran tahfiz al-Qur'an yang diperioritaskan mulai kelas 3 sampai kelas 6. Adapun pelaksanaan pembelajaran tahsin dan tahfiz al-Qur'an dengan menggunakan metode talaqqi di kelas 3 SDIT Khaira Ummah Tanjungsari dibagi menjadi 3 kelompok, yaitu: Kelompok A, merupakan kelompok dengan tingkat mahir atau kelompok siswa yang sudah lancar membaca al-Qur'an dan rata-rata hafal juz 30. Kelompok B, merupakan kelompok dengan tingkatan kurang lancar, yaitu kelompok siswa yang sudah bisa membaca al-Qur'an namun tingkat kesalahannya masih cukup banyak dan Kelompok C, merupakan kelompok dengan tingkatan kemampuan siswa belum lancar dalam membaca al-Qur'an atau masih terbata-bata. Untuk kegiatan pelaksanaannya baik dari kelompok A, B maupun kelompok C dimulai dengan kegiatan 
pra pembelajaran, kegiatan pembuka, kegiatan inti dan kegiatan penutup. Dalam metode talaqqi ini biasanya dilakukan secara jama'i (klasikal) yaitu seorang guru mencontohkan bacaan di depan para siswa dalam satu kelompok dan setelah menyimak bacaan guru kemudian siswa diminta untuk menirukan bacaan yang dicontohkan oleh guru, dan biasanya ini dilakukan secara private (individual) yaitu seorang peserta didik berhadapan langsung dengan guru, supaya dapat diketahui bagaimana kemampuan siswa satu-persatu. Adapun waktu pelaksanaan pembelajaran tahsin dan tahfiz al-Qur'an adalah 2 jam pelajaran atau $2 \times 35$ menit.

Ruang lingkup penilaian dalam implementasi metode talaqqi pada pembelajaran tahsin dan tahfiz al-Qur'an di kelas III SDIT Khaira Ummah Tanjungsari mencakup pengujian terhadap hasil belajar peserta didik pada aspek kognitif, afektif, dan psikomotor. Bentuk penilaiannya terdiri atas beberapajenis tagihan, yaitu; kuis, pertanyaan lisan, tugas individu, responsi atau ujian praktik, ulangan harian dan lain-lain. Berdasarkan hasil evaluasi yang di laksanakan kepada kelompok A, kelompok B dan juga kelompok C, dalam implementasi metode talaqqi pada pembelajaran tahsin dan tahfiz al-Qur'an di kelas III SDIT Khaira Ummah Tanjungsari terdapat faktor pendukung dan penghambat. Diantara faktor pendukung yaitu faktor kebijakan sekolah, faktor sarana dan prasarana, Faktor masyarakat dan lingkungan sekitar, faktor lokasi sekolah dan faktor peseta didik. Adapun faktor penghambat atau beberapa permasalahan dalam pembelajaran tahsin dan tahfiz al-Qur'an di kelas III SDIT Khaira Ummah Tanjungsari dengan menggunakan metode talaqqi terbagi menjadi 2 faktor, yaitu yang bersumber dari pengajar dan bersumber dari siswa. Pertama, dari faktor pengajar diantaranya: terbatasnya jumlah pengajar, kurangnya variasi tehnik yang digunakan dalam metode talaqqi, pengelolaan keras yang kurang kondusif, kurang mampu memonitoring kemampuan siswa, komunikasi yang kurang baik antar pengajar tahsin dan tahfiz al-Qur'an, menejemen waktu dan Lemahnya komunikasi dengan orang tua atau wali murid. Kedua, dari faktor siswa diantaranya: latar belakang siswa, semangat siswa yang naik turun, daya serap siswa yang berbeda-beda, Siswa kurang konsentrasi terhadap materi tahsin dan tahfiz al-Qur'an, perbedaan cara belajar antar individu siswa dan kurangnya disiplin siswa.

\section{DAFTAR PUSTAKA}

Abdul Khaliq, A. (2006). Bagaimana Menghafal al-Qur'an. Jakarta: Pustaka Al-Kautsar.

Annuri, A. (2013). Panduan Tahsin Tilawah al-Qur'an dan Ilmu Tajwid. Jakarta: Pustaka Kautsar.

Anshori, A. (2014). Syarah Risalah al-Ubudiyyah. Jakarta: Dar Ibnul Jauzi.

Az-Zawawi, Y. F. (2010). Revolusi Menghafal al-Qur'an. Surakarta: Insane Kamil.

Badwilan, A. S. (2011). Panduan Cepat Menghafal al-Qur'an. Yogyakarta: Diva Press.

Buckley Philip dan Irawan. (2015). The Scientific Paradigm of Islamic Education Management:

Phenomenology Perspective. Jurnal Pendidikan Islam, 2(1).

Hanapi, A. (2014). Materi Praktis Tahsin Tilawah Metode Tar-Q. Bandung: Tar-Q Press.

Irawan. (2016). Paradigma Keilmuan Manajemen Pendidikan Islam. Manageria: Jurnal Manajemen Pendidikan Islam, 1(2).

Kurnaedi, A. Y. (2014). Tajwid Lengkap as-Syafi'i. Jakarta: Pustaka Imam as-Syafi'i.

Suryabrata, S. (2013). Metodologi Penelitian. Jakarta: PT Raja Grafindo Persada.

Wahid, W. A. (2013). Cara Cepat Bisa Menghafal al-Qur'an. Jogjakarta: Diva press. 